\title{
Spinal Muscle Atrophy: Clinical Cases
}

\section{Atrofia Muscular Espinhal: Casos Clínicos}

\author{
Pamela Tainá Licoviski*a; Clara Victoria Binia; Alisson Grégori Turskia; Greicy Kelly de Oliveira Brunoa; Luana \\ Cristina Borchardta; Ana Carolina Dorigoni Bini ${ }^{\mathrm{a}}$
}

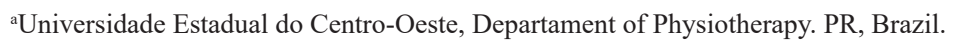

*E-mail: pamelalicoviski@gmail.com.

\begin{abstract}
Spinal muscular atrophy (EBF) is an autosomal recessive neuromuscular disease with genetic inheritance. EBF is classified into: type I patients have symptoms up to 6 months of age; type II - after 6 months of age, symptoms begin; type III - it starts after 18 months of age. The objective of this study was to clinically characterize two brothers diagnosed with EBF. It is a clinical case study of two individuals, male gender, attended at Clínica Escola de Fisioterapia, at Universidade Estadual do Centro Oeste do Paraná- UNICENTRO, Campus CEDETEG. Selected by eligibility both were diagnosed with spinal muscular atrophy. The physiotherapy stages evaluation was carried out, which consist of anamnesis, functional examination, physical examination and respiratory evaluation. Patient 1, was diagnosed with EBF type IIIb at 16 years old, with reports of falls and weakness mainly in lower limbs, in the evaluation positive Gowers sign, anserine gait, hypotonic, MMSS areflexia and lower limb hyporeflexia, breathing pattern apical were found. Patient 2 was diagnosed with EBF type IIIa at 1 year of age, currently using a wheelchair for locomotion, on physical examination he had scoliosis with right convexity, deformities in the costal grid, decreased muscle strength in the upper limbs and lower limbs, mixed respiratory pattern. From the physical therapy evaluation performed on these patients, it could be noted that the weakness of the respiratory muscles is directly related to the clinical sign presented by both.
\end{abstract}

Keywords: Physiotherapy Specialty. Neuromuscular Diseases. Spinal Muscular Atrophy.

\section{Resumo}

A atrofia muscular espinhal (AME) é uma doença neuromuscular autossômica recessiva com herança genética. A AME é classificada em: tipo I-pacientes apresentam sintomas até 6 meses de idade; tipo II - após os 6 meses de idade inicia-se os sintomas; tipo III - inicia-se após 18 meses de idade. O objetivo desse trabalho foi caracterizar clinicamente dois irmãos com diagnóstico de AME. É um estudo de casos clínicos de dois individuos, do gênero masculino, atendidos na Clínica Escola de Fisioterapia, da Universidade Estadual do Centro Oeste do Paraná - UNICENTRO, Campus CEDETEG. Selecionados por elegibilidade ambos diagnosticados com atrofia muscular espinhal. Foram realizadas as etapas da avaliação fisioterapêutica que consistem em anamnese, exame funcional, exame físico e avaliação respiratória. O paciente 1, foi diagnosticado com AME tipo IIIb aos 16 anos, com relatos de quedas e fraqueza principalmente em MMII, na avaliação constatou-se, sinal de Gowers positivo, marcha anserina, hipotônico, arreflexia de MMSS e hiporeflexia de MMII, padrão respiratório apical. O paciente 2 recebeu o diagnóstico de AME tipo III a com 01 ano de idade, atualmente utiliza cadeira de rodas para locomoção, no exame fisico apresenta escoliose com convexidade a direita, deformidades no gradil costal, força muscular diminuída em MMSS e MMII, padrão respiratório misto. A partir da avaliação fisioterapêutica realizada nesses pacientes, pode-se notar que a fraqueza dos músculos respiratórios está diretamente relacionada com o quadro clinico apresentado por ambos.

Palavras-chave: Fisioterapia. Doenças Neuromusculares. Atrofia Muscular Espinhal.

\section{Introduction}

Spinal muscular atrophy $(\mathrm{EBF})$ is an autosomal recessive neuromuscular disease with genetic inheritance. AME was originally described by Guido Werning and Johann Hoffmann between 1891 and $1900^{1}$, a century later, genetic advances allowed the identification and localization of the motor survival gene $(\mathrm{SMN} 1)$ as the cause of the disease ${ }^{2}$. The homozygous mutation or deletion of the SMN1 gene is the cause by which it results in the development of AME, the determinant for AME clinical phenotype and its severity is defined by the SMN protein transcription, which is transcribed by the SMN2 gene, a copy of the SMN1 gene, which is located on chromosome $5 q 13^{3,4}$. Degeneration of motor neurons of the anterior horn of the spinal cord results in progressive muscle atrophy and weakness ${ }^{5}$. AME is classified into three types, according to functional capacity: Type I - patients present symptoms up to 6 months of age and do not sit alone; Type II - after 6 months of age, muscle weakness begins, individuals sit, but do not walk; Type III - starts after 18 months of age, individuals can walk $^{6,7}$.

AME type I (severe): It is characterized by early development time ( 0 to 6 months of age), showing lack of ability to sit without support and short life expectancy ${ }^{8}$. AME type II (chronic): Symptomatic about 6 to 18 months of life, however it may manifest before that. Some individuals can sit alone while others are only positioned, with this they can 
develop scoliosis and contractures over the years, and the life expectancy of these individuals is around 10 to 40 years 9 . AME type III (juvenile): It is present after 18 months of age, however, the age at onset varies greatly ${ }^{10}$. The disease onset before the age of 3 is classified as type IIIa AME, whereas after this age it is defined as type IIIb AME. What differentiates both of them is the preserved ability to walk, and individuals with type IIIa are able to walk up to 20 years of age, however, type IIIb individuals of the same age remain capable of walking throughout life ${ }^{11}$.

AME is considered a severe pathology that affects 1 in 6000-10000 newborns. It presents clinical manifestations that occur early in the prenatal period through the reduction of fetal movements, at birth or before 6 months of life, in which the individual presents hypotonia to muscle palpation, global weakness of the proximal muscles of arms and legs that are usually the most affected, and eventually, ${ }^{12,13}$ of trunk muscles, absence of active movements, absence of trunk and cervical control, evolving to severe respiratory and motor involvement.

Thus, this study aims to report clinically two brothers with AME diagnosis, who were attended at the Physiotherapy Clinical School, of Universidade Estadual do Centro Oeste do Paraná - UNICENTRO, Campus CEDETEG.

\section{Case Report}

The study was developed at the Physiotherapy School Clinic of Universidade Estadual do Centro Oeste do Paraná UNICENTRO, CEDETEG Campus, in the city of GuarapuavaPR. The physiotherapeutic evaluation consisted of anamnesis, functional examination and physical examination in both individuals.

The physical evaluation instruments used were a goniometer of the brand (Arktus) to verify the range of movements of MMSS, MMII. Muscle strength was evaluated through the MRC-Medical Research Council scale (it evaluates 12 muscle groups, a total score below 48/60 designates significant weakness, and a total MRC score below 36/48 indicates severe weakness ${ }^{14}$ ), manual grip was evaluated through a dynamometer (Crown Manual $100 \mathrm{kgf}$ ), the special tests used were the EK-Engen Klassifikation questionnaires for functional AME evaluation (it is divided into 10 categories, each of them with four alternative, which provide partial scores between zero and three. A total score is obtained by the sum of the partial scores and varies between 0 and 30. The higher the degree of functional impairment, the higher the score obtained ${ }^{15}$ ), MFM - measurement of the gross motor function for neuromuscular diseases (it is composed of 32 items, divided into 3 dimensions: Dimension 1 - standing posture and transfers, with 13 items; Dimension 2 - axial and proximal motor function, with 12 items; Dimension 3 - distal motor function, with seven items. Each item is scored from 0 to 3 , with zero not performing the movement or not maintaining the position, 1 performing partially, 2 performing slowly or with offsets, and 3 performing correctly. The partial and total scores of the dimensions are expressed as a percentage in relation to the maximum score of 96 points ${ }^{16}$ ), Barthel Index for the evaluation of functional independence (it is composed of ten items, which assess diverse aspects, such as ability to feed, dress, personal hygiene and movement. The partial scores obtained range from 0 to 10 or 0 and 15 . The total score obtained range from 0 to 100 . High values of the Barthel index indicate lower functional commitment ${ }^{15}$ ) and TUG (timed up and go test) for assessing functional mobility and dynamic balance in which it consists of getting up from a chair without the help of the arms and walking at a comfortable and safe pace at a distance of three meters, walking around, returning and sitting. At the beginning of the test, the participant remained with the back resting on the seat back and should return to this position at the end of the test $\mathrm{t}^{17}$. For respiratory evaluation, the chest type, apical and xiphoid expansibility, diaphragmatic muscle strength, respiratory rhythm, respiratory pattern, expiratory flow through peak flow (Philips Respironics), chest cytometry in axillary, xiphoid and basal regions were evaluated using measuring tape, chest symmetry, axillary and xiphoid force, Charpy angle, inspiratory and expiratory force which were evaluated through the Manovacuometry (Comercial Medica).

This is a case report of two male individuals, selected for eligibility both diagnosed with spinal muscular atrophy, which followed the norms recommended by the National Health Council (CNS) for research with human beings and the National Committee on Ethics in Research (CONEP), and all evaluated patients signed the free and informed consent form, approved by the Ethics Committee of Universidade Estadual do Centro-Oeste (UNICENTRO) opinion number 3.594.701.

\subsection{Case 1}

A 27-year-old male patient, A.R.J., was diagnosed with type IIIb spinal muscle atrophy at 16 years of age. The same reported that he suffered many falls and felt weakness mainly in the lower limbs, so he sought medical assistance. This patient has been receiving physiotherapeutic care since he was 15 years old. The same goes for supplementation with vitamins B12, Magnesium and Omega 3 and also makes use of Durabolim anabolic. In the functional exam, the patient presented a positive Gowers signal, and the patient's gait pattern is Anserine type. The patient also reported that he performs all the postural changes, but has difficulties due to muscle weakness. At the time of physical examination in May 2020 , the patient weighed $63 \mathrm{~kg}$, with $173 \mathrm{~cm}$ height, blood pressure was $110 / 70 \mathrm{mmHg}$, heart rate was $82 \mathrm{bpm}$, respiratory rate was $16 \mathrm{irpm}$ and saturation was $98 \%$.

Trunk range of motion (ADM) shows $45^{\circ}$ flexion, $5^{\circ}$ extension, $45^{\circ}$ lateral flexion for both sides and $180^{\circ}$ rotation for both sides. The range of movement of upper limbs is normal. He presents arreflexia in the upper limbs and the 
musculature is hypotonic. MRC was 44/60, being right side 22 and left side 22. In the lower limbs, the range of motion is reduced in the following movements: hip flexion $\left(120^{\circ}\right.$ in the right and $125^{\circ}$ in the left) as well as hip adduction (left/right $\left.10^{\circ}\right)$, dorsiflexion $\left(15^{\circ}\right.$ in the right limb and $10^{\circ}$ in the left) and plantar flexion $\left(20^{\circ}\right.$ in both limbs). He shows hyporeflexia (patellar and aquileu reflex). There is also a difference in limbs length $(91 \mathrm{~cm}$ on the right limb and $93 \mathrm{~cm}$ on the left). In Engen Klassifikation scale, this patient scored 1. The Barthel index resulted in 100 points (independent) and the Timed Up and Go (TUG) test resulted in 12 seconds (with partial independence and low risk of falls). In MFM, the result was $100 \%$ indicating total independence.

In the respiratory evaluation, the patient presented normal chest, with normal apical, xiphoid and basal expansion, with normal anterior/posterior expansion. Dyspneic breathing rhythm when traveling at higher speed is necessary. The patient's breathing pattern is apical. Cytometry showed normal values (Table 1).

Table 1 - Case 1 cytometry values, performed at the School of Physiotherapy Clinic, in 2019

\begin{tabular}{|c|c|}
\hline Region & Inspiration/Expiration difference \\
\hline Axillary & $4 \mathrm{~cm}$ \\
\hline Xiphoidian & $7 \mathrm{~cm}$ \\
\hline Abdominal & $3 \mathrm{~cm}$ \\
\hline
\end{tabular}

Source: Research data.

Normolineal Charpy angle (Chart 2). In diaphragmatic evaluation, he presented grade 2 with normal tonus, normal expansibility and decreased strength. Manovacuometry showed respiratory muscle weakness and Peak Flow showed normal expiratory flow for the patient (Table 2).

Table 2 - Respiratory Evaluation of case 1, performed at the School of Physiotherapy Clinic, in 2019

\begin{tabular}{|c|c|c|c|}
\hline $\begin{array}{c}\text { Breathing } \\
\text { pattern }\end{array}$ & $\begin{array}{c}\text { Charpy } \\
\text { angle }\end{array}$ & Manovacuometry & $\begin{array}{c}\text { Peak } \\
\text { Flow }\end{array}$ \\
\hline Apical & $\begin{array}{c}90^{\circ} \\
\text { (normolineal) }\end{array}$ & $\begin{array}{c}133.7 \mathrm{~cm} \mathrm{H} 2 \mathrm{O}(\mathrm{PImax}) \\
137.4 \mathrm{cmH} 2 \mathrm{O}(\mathrm{PEmax})\end{array}$ & $\begin{array}{c}810 \\
\mathrm{~cm} / 1\end{array}$ \\
\hline
\end{tabular}

Source: Research data.

\subsection{Case 2}

Patient 1, 14 years old, male, received the AME type IIIa diagnosis when he was 01 year old, since then has performed physiotherapy.

He reports that he walked independently until the age of 10 , and currently uses wheelchair for locomotion. At the time of physical examination in May 2019, the patient weighed 32 $\mathrm{kg}$, with $170 \mathrm{~cm}$ height, blood pressure was $110 / 60 \mathrm{mmHg}$, heart rate was $76 \mathrm{bpm}$, respiratory rate was $18 \mathrm{irpm}$ and saturation was $96 \%$.

The patient presents scoliosis with convexity to the right and deformities in the costal grid. Trunk range of motion not evaluated due to deformity (Figures 1 and 2). In the upper limbs the range of motion is normal. He presents arreflexia in the upper limbs and the musculature is hypotonic. In the lower limbs, there were reduced motion amplitudes in dorsiflexion ( $5^{\circ}$ in the right ankle and $18^{\circ}$ in the left ankle) and plantar flexion ( $20^{\circ}$ in the left ankle and $40^{\circ}$ in the right ankle). MRC was 34/60, being left side 17 and right side 17 . He has lower limbs areflexia. In Engen Klassifikation scale, this patient scored 16. The Barthel index resulted in 40 points (dependent) and the Timed Up and Go (TUG) test was not performed in this patient due to locomotion. On the MFM scale, it was 70\%, with compromised independence.

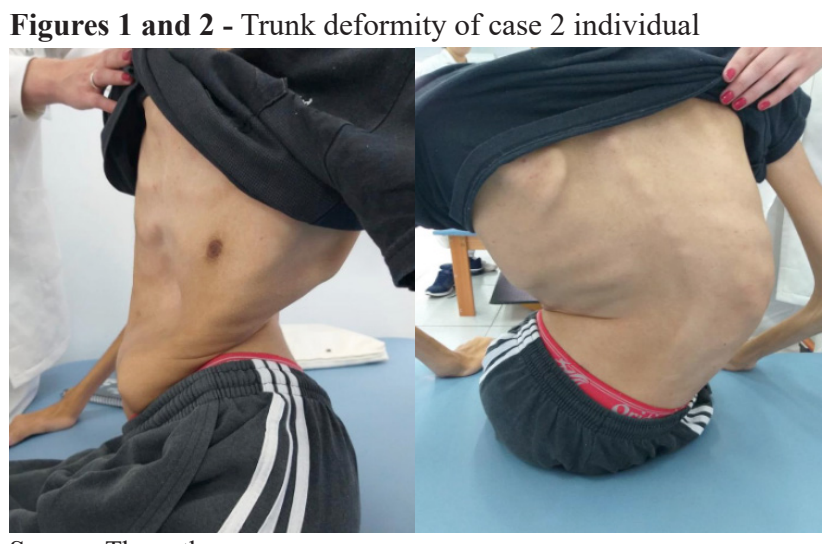

Source: The authors.

The patient's chest is a kyphoscolitic type. Reduced apical, xiphoidian, and basal anterior/posterior expansibility. Eupneic respiratory rhythm. Cytometry showed normal values (Table 3).

Table 3 - Case 2 cytometry values, performed at the School of Physiotherapy Clinic, in 2019

\begin{tabular}{|c|c|}
\hline Region & Inspiration/Expiration difference \\
\hline Axillary & $4 \mathrm{~cm}$ \\
\hline Xiphoidian & $3.5 \mathrm{~cm}$ \\
\hline Abdominal & $3.5 \mathrm{~cm}$ \\
\hline
\end{tabular}

Source: Research data.

The respiratory pattern of the patient is mixed and the angle of Charpy longilineal (Chart 4). In diaphragmatic evaluation, he presented grade 2 with normal tonus, normal expansibility and decreased strength. Manovacuometry showed respiratory muscle weakness and Peak Flow showed normal expiratory flow for the patient (Table 4).

Table 4 - Respiratory Evaluation of case 2, performed at the School of Physiotherapy Clinic, in 2019

\begin{tabular}{|c|c|c|c|}
\hline $\begin{array}{c}\text { Breathing } \\
\text { pattern }\end{array}$ & $\begin{array}{c}\text { Charpy } \\
\text { angle }\end{array}$ & Manovacuometry & $\begin{array}{c}\text { Peak } \\
\text { Flow }\end{array}$ \\
\hline Mixed & $\begin{array}{c}<90^{\circ} \\
\text { (longilineal) }\end{array}$ & $\begin{array}{c}143.3 \mathrm{~cm} \mathrm{H} 2 \mathrm{O}(\text { PImax) } \\
103.45 \mathrm{~cm} \mathrm{H} \text { O (PEmax) }\end{array}$ & $590 \mathrm{~cm} / 1$ \\
\hline
\end{tabular}

\section{Source: Research data.}

\subsection{Discussion}

Respiratory muscle weakness is frequent in neuromuscular diseases and is directly associated with morbidity and mortality of these patients. Several complications may affect patients with AME, such as postural alterations, decrease in the range 
of motion, changes in gait, motor and respiratory alterations, and basically all respiratory alterations are due to the fact that progressive respiratory muscle weakness occurs, as with other skeletal muscles that are affected by this disease ${ }^{18,19}$.

Respiratory complications are difficult to treat and often cause respiratory failure and death, where pulmonary diseases are the main cause of morbidity and mortality in patients with AME, particularly in patients with AME I and II, and may also occur, although in a lower proportion, in AME III. Immobility associated with AME increases muscle atrophy and may determine axial deviations and limbs deformities ${ }^{20}$. Types II and III, associated with higher survival, but also with increasing immobility and the use of wheelchair for ambulation $^{21}$. Scoliosis is described in $50 \%$ of patients with $\mathrm{AME}$, and it is more frequent in patients who have never performed gait or have lost capacity ${ }^{22}$. The findings obtained in the present study show respiratory alterations, due to postural maladjustment caused by spinal muscle atrophy, where there was a scoliosis generated by the evolution of the disease, in which the inadequate posture generated compression of organs and viscera, which was solved by surgical correction.

In general, motor unit diseases are associated with decreased bone mineral density (BMD) due to disuse. ${ }^{23,24}$ For this pathological state, the immobilization/reduction of mobility and locomotion, which simultaneously condition a reduction in the forces applied to the bone by muscular contraction and severity, and the decrease in the bone remodeling threshold with consequent reduction in trabecular and endocortical BMD. The earlier the disease starts and the longer the survival, the worse the prognosis, in terms of the number of fractures and gait capacity, due to a cycle of immobility, reduction of BMD, pathological fracture and so on $^{25}$.

When there is respiratory muscle weakness, there is a high incidence of ventilatory insufficiency, thus justifying the strengthening of respiratory muscles as a form of prevention ${ }^{18,19}$. In the present study, respiratory muscle weakness is shown by respiratory evaluation, with specific instruments, such as peak flow and manovacuometry, in which manovacuometry was decreased in individuals with spinal muscle atrophy III. In some studies, type III presented a higher expiratory peak, since it is a more heterogeneous group, composed of individuals who maintain ambulation, wheel-chair users and people with and without spinal deformities ${ }^{26}$. In the present report, one of the individuals obtained the expiratory flow without alterations, in which the same ambulates and does not present deformities.

Maintaining proper body alignment, preventing spinal compensation - especially in patients with scoliosis - benefits respiratory function. These results show this: statistically significant values were found in the patients' $\mathrm{MV}, \mathrm{VC}, \mathrm{CFV}$, MIP, MEP and PEF when sitting in their chairs with postural adequacy than in the standard chair, without adaptation to suit the posture. Comparing the two situations, the postural adequacy system resulted in an increase of $16 \%$ in $\mathrm{MV}, 30 \%$ in VC, $25 \%$ in CFV, $46 \%$ in MIP, $37 \%$ in MEP and $19 \%$ in $\mathrm{PEF}^{27}$.

Adaptations made specifically for the patient in his wheelchair provide better positioning and trunk stabilization, unlike the standard chair without postural fit. It is believed that the best biomechanical alignment offered by this resource positively influences the performance of the structures involved in breathing, contributing to minimize the possibility of a worsening of the respiratory function resulting from the sitting posture with mechanical compensation and blockages to the chest and abdomen, since such patients are already affected by progressive deterioration of the strength of the muscles involved ${ }^{27}$.

Because of the severity of muscle weakness and because they are always lying or rising very little, these patients have a limited ability to cough and clean secretions present in the lower airways. As a result, recurrent infections may occur, which exacerbate muscle weakness (mainly respiratory muscles) and may also result in atelectasis and pulmonary collapse $^{20}$. The immobility of these patients leads to alterations in the range of movement of the joints, where it is decreased in one of the individuals in the case report, corroborating, for generalized muscle weakness generating hypotonia, joint and muscular contractures, postural maladjustments, and consequently impairing the gait of these individuals, who before could walk and after a while they started to use a wheelchair. Type III has a milder start with highly variable travel. Patients are able to walk without care for a significant period of time and have a life expectancy close to normal. The involvement is predominantly proximal, with involvement of the pelvic waist and later of the scapular waist. The disease can progress rapidly during adolescence, leading to disability in the second decade, while at other times it is limited to a discreet commitment of the proximal muscles of the limbs ${ }^{28}$.

As we have seen, spinal muscular atrophy is characterized by a hypotonia that generates a muscular atrophy, which directly influence the respiratory and motor impairment of patients presenting this pathology. We also suggest that the research be carried out with a greater number of samples, and that the evaluation and intervention of the individuals be performed.

\section{Conclusion}

Spinal muscular atrophy is characterized by a hypotonia, a condition that may lead patients to infections that may result in some respiratory complications such as atelectasis and pulmonary collapse. Thus, it is concluded that from physiotherapeutic evaluation performed in such patients, that the respiratory muscles weakness is directly associated to the clinical signs presented by both. 


\section{References}

1. Dubowitz V. Ramblings in the history of spinal muscular atrophy. Neuromusc Dis. NMD 2009;19(1):69-73. doi: https://doi.org/10.1016/j.nmd.2008.10.004

2. Lefebvre S, Burglen L, Reboullet S, Clermont O, Burlet $\mathrm{P}$, Viollet L, et al. Identificação e caracterização de um gene determinante de atrofia muscular espinhal. Cell 1995;80:15565. doi: https://doi.org/10.1590/S0021-75572010000400004

3. Araújo AP, Ramos VG, Cabello PH. Dificuldades diagnósticas na atrofia muscular espinhal. Arq Neuropsiquiatr 2005;63(1):145-9. doi: https://doi.org/10.1590/S0004282X2005000100026

4. Russman BS. Spinal muscular atrophy: clinical classifications and disease heterogeneity. J Child Neurol 2007;22(8):946-51. doi: $10.1177 / 0883073807305673$

5. Swoboda KJ, Prior TW, Scott CB, McNaught TP, Wride $\mathrm{MC}$, Reyna SP, et al. Natural history of denervation in SMA: relation to age, SMN2 copy number, and function. Ann Neurol 2005;57(5):704-12. doi: 10.1002/ana.20473

6. Wang $\mathrm{CH}$, Finkel RS, Bertini ES, Schroth M, Simonds A, Wong B, et al. Consensus statement for standard of care in spinal muscular atrophy. J Child Neurol 2007;22(8):1027-49. doi: $10.1177 / 0883073807305788$.

7. Markowitz JA, Singh P, Darras BT. Spinal muscular atrophy: a clinical and research update. Pediatr Neurol 2012;46(1):112. doi: 10.1016/j.pediatrneurol.2011.09.001

8. Russman BS. Spinal muscular atrophy: clinical classifcations and disease heterogeneity. J Child Neurol 2007;22:946-51. doi: https://doi.org/10.1177/0883073807305673

9. Wang CH, Finkel RS, Bertini ES, Schroth M, Simonds A, Wong B, et al. Consensus statement For standard of care in spinal muscular atrophy. J Child Neurol 2007;22:1027-49. doi: https://doi.org/10.1542/peds.2008-2952K

10. Wirth B, Brichta L, Hahnen E. Spinal muscular atrophy: From gene to therapy. Semin Pediatr Neurol 2006;13:121-31. doi: https://doi.org/10.1016/j.spen.2006.06.008

11. Zerres K, Rudnik-Schöneborn S. Natural history in proximal spinal muscular atrophy. Clinical analysis of 445 patients and suggestions. For a modifcation of existing classifcations. Arch Neurol 1995;52:518-23. doi: 10.1001/ archneur.1995.00540290108025

12. Ryder S, Leadley RM, Armstrong N. et al. The burden, epidemiology, costs and treatment for Duchenne muscular dystrophy: an evidence review. Orphanet J Rare Dis 2017;12:79. doi: https://doi.org/10.1186/s13023-0170631-3

13. Talbot K.; Tizzano EF. The clinical landscape for SMA in a new therapeutic era. Gene Ther 2017;24(9):529-33. doi: https://doi.org/10.1038/gt.2017.52

14. Latronico N, Gosselink R. Abordagem dirigida para o diagnóstico de fraqueza muscular grave na unidade de terapia intensiva. Rev Bras Ter Intensiva 2015;27(3):199-201. doi: https://doi.org/10.5935/0103-507X.20150036.

15. Martinez J, Brunherotti, MA, Assis MR, Sobreira CFR.
Validação da escala motora funcional EK para a língua portuguesa. Rev Assoc Med Bras 2006;52(5):347-51. doi: https://doi.org/10.1590/S0104-42302006000500024.

16. Souza PC, Rodrigues F, Souza PS, Berlink M, Tuon L. Medida da função motora nas distrofias musculares progressivas: uma nova alternativa para avaliação fisioterapêutica. Fisioter Brasil 2012;13(2):109-12.

17. Wamser EL, Valderramas S, Paula JÁ, Schieferdecker ME. Melhor desempenho no teste timed up and go está associado a melhor desempenho funcional em idosas da comunidade. Geriatr Gerontol Aging 2015;9(4):138-43. doi: 10.5327/Z2447-2115201500040003

18. Birkant DJ. The Assessment and Management of the Respiratory Com- plications of Pediatric Neuromuscular Diseases. Clin Pediatr 2002;41:301-8. doi: https://doi. org $/ 10.1177 / 000992280204100502$

19. Estrup C, Lyager S, Naeraa N, Olsen C. Effect of respiratory muscle training in patients with neuromuscular disease and in normal. Respiration 1986;50:36-43. doi: 10.1159/000194904.

20. Baioni MTC, Ambiel CR. Atrofia muscular espinhal: diagnóstico, tratamento e perspectivas futuras. J Pediatr 2010;86(4):261-70. doi: https://doi.org/10.1590/S002175572010000400004

21. Ward S, Chatwin M, Heather S, Simonds AK. Randomised controlled trial of non-invasive ventilation (NIV) for nocturnal hypoventilation in neuromuscular and chest wall disease patients with daytime normocapnia. Thorax 2005;60:101924. doi: 10.1136/thx.2004.037424

22. De Groot IJ, De Witte LP. Physical complaints in ageing persons with spinal muscular atrophy. J Rehabil Med 2005;37:258-62. doi: 10.1080/16501970510030156

23. Rodillo E, Marini ML, Heckmatt JZ, Dubowitz V. Scoliosis in spinal muscular atrophy: review of 63 cases. J Child Neurol 1989;4:118-23. doi: 10.1177/088307388900400208

24. Baroncelli GI, Bertelloni S, Sodini F, Saggese G. Osteoporosis in Children and Adolescents: Etiol Manag Pediatr Drugs 2005;7(5):295-323. doi: 10.2165/00148581-20050705000003

25. Pires M, Marreiros H, Vieira JP. Atrofia muscular espinhal: análise descritiva de uma série de casos. Acta Med Port 2011;24(2):95-102. doi: http://hdl.handle.net/10400.17/877

26. De Souza CPV, Ribeiro RKC, Lima LV, Sant'Anna CC, Araújo APQC. Pico de fluxo de tosse em crianças e jovens com atrofia muscular espinhal tipo II e tipo III. Fisioter Pesq 2018;25(4):432-7. doi: https://doi.org/10.1590/18092950/18002025042018

27. Collange LA. Influência da adequação postural em cadeira de rodas na função respiratória de pacientes com amiotrofia espinhal tipo II. Fisioter Pesq 2009;16(3):229-32. doi: https:// doi.org/10.1590/S1809-29502009000300007

28. Orsini M, Freitas MR, Sá MRC, Mello MP, Botelho JP, Antonioli $\mathrm{R}$, et al. Uma revisão das principais abordagens fisioterapêuticas nas atrofias musculares espinhais. Rev Neuroc 2008;16(1):46-52. doi: https://doi.org/10.34024/ rnc.2008.v16.8664. 